MOLECULAR ASPECTS OF ANTICANCER DRUG-DNA INTERACTIONS

Volume 2 


\section{TOPICS IN MOLECULAR AND STRUCTURAL BIOLOGY}

\section{Series Editors}

Stephen Neidle

Institute of Cancer Research

Sutton, Surrey, UK

Watson Fuller

Department of Physics

University of Keele, $U K$

Jack S. Cohen

Georgetown University

USA

\section{Recent titles}

Protein-Nucleic Acid Interaction

Edited by Wolfram Saenger and Udo Heinemann (1989)

Calcified Tissue

Edited by David W. L. Hukins (1989)

Oligodeoxynucleotides: Antisense Inhibitors of Gene Expression Edited by Jack S. Cohen (1989)

Molecular Mechanisms in Muscular Contraction

Edited by John M. Squire (1990)

Connective Tissue Matrix, Part 2

Edited by David W. L. Hukins (1990)

New Techniques of Optical Microscopy and Microspectroscopy

Edited by Richard J. Cherry (1990)

Molecular Dynamics: Applications in Molecular Biology

Edited by Julia M. Goodfellow (1990)

Water and Biological Macromolecules

Edited by Eric Westhof (1993) 
Topics in Molecular and Structural Biology

\title{
MOLECULAR ASPECTS OF ANTICANCER DRUG-DNA INTERACTIONS Volume 2
}

\author{
Edited by \\ Stephen Neidle \\ Institute of Cancer Research \\ Sutton, Surrey, UK \\ and \\ Michael Waring \\ Dept of Pharmacology \\ University of Cambridge
}

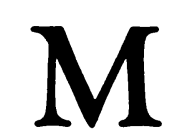

MACMILLAN 
(C) The contributors 1994

Softcover reprint of the hardcover 1st edition 1994

All rights reserved. No reproduction, copy or transmission of this publication may be made without written permission.

No paragraph of this publication may be reproduced, copied or transmitted save with written permission or in accordance with the provisions of the Copyright, Designs and Patents Act 1988, or under the terms of any licence permitting limited copying issued by the Copyright Licensing Agency, 90 Tottenham Court Road, London W1P 9HE.

Any person who does any unauthorised act in relation to this publication may be liable to criminal prosecution and civil claims for damages.

First published 1994 by

THE MACMILLAN PRESS LTD

Houndmills, Basingstoke, Hampshire RG21 2XS

and London

Companies and representatives

throughout the world

ISBN 978-1-349-13332-1

DOI 10.1007/978-1-349-13330-7

ISSN 0265-4377

A catalogue record for this book is available from the British Library 


\section{Contents}

The Contributors viii

Preface $\quad x$

1 DNA topoisomerases $R . K$. Ralph, W. Judd,

Y. Pommier and K. W. Kohn

1 Introduction

2 Topoisomerase I (top I) 3

3 Topoisomerase II (top II) 24

4 Conclusions 66

2 Cellular and molecular pharmacology of the anthrapyrazole antitumour agents L. H. Patterson and D. R. Newell 96

1 Introduction 96

2 Rationale for development of the anthrapyrazoles 96

3 Structural requirements for anthrapyrazole antitumour

4 Cellular pharmacology of the anthrapyrazoles $\quad 110$

5 Molecular pharmacology of the anthrapyrazoles 112

6 Activation of anthrapyrazoles in biological systems 117

7 Preclinical and clinical pharmacology of the anthrapyrazoles 123

8 Conclusions 123

3 Calicheamicin G. A. Ellestad and W.-d. Ding 130

1 Introduction 130

2 Isolation, structure and chemistry 131

3 Affinity of calicheamicin $\gamma_{1}^{\mathrm{I}}$ for DNA 135

4 Plasmid DNA cleavage studies 136

5 DNA binding/cleavage specificity 137 
6 Structural features important for DNA binding and discrimination

7 NMR evidence for solution conformation

8 Evidence for a hydrophobic contribution to the calicheamicin-DNA association

9 DNA cleavage chemistry

10 Mechanism of trisulfide cleavage

11 Biochemical basis for cytotoxicity

12 Summary

13 Addendum

4 Molecular pharmacology of intercalator-groove binder hybrid molecules

C. Bailly and J.-P. Hénichart

2 Isolexins, lexitropsins and combilexins

3 Naturally occurring multivalent molecules 167

4 Netropsin-acridine hybrid molecules 168

5 Distamycin-ellipticine hybrid molecules 178

6 Intercalator-peptide conjugates 181

7 Conclusion

5 Bleomycins: Mechanism of polynucleotide recognition and oxidative degradation $A$. Natrajan and $S$. M. Hecht

2 Oxygen activation by iron bleomycin

3 Other metallobleomycins

4 Interaction of bleomycin with DNA

6 Kinetic analysis of drug-nucleic acid binding modes:

\section{Absolute rates and effects of salt concentration}

W. D. Wilson and F. A. Tanious

1 Introduction

2 Nucleic acid binding modes

3 Ion effects on nucleic acid structure and interactions

4 Quantitative aspects

5 Methods

6 Applications to drug-nucleic acid complexes: Classical

7 Association reactions

8 Dissociation reactions

9 Mechanism of nucleic acid-drug interactions 
7 Acridine-based anticancer drugs W. A. Denny and

B. C. Baguley

1 Introduction

2 9-Anilinoacridines

3 Acridinecarboxamides

4 Nitroacridines

5 Polyacridines

286

6 Acridines as carriers for other functionalities

7 Acridine alkaloids

8 Acridones

9 Conclusions

8 The mitomycins: Natural cross-linkers of DNA M. Tomasz

1 Introduction

2 Reductive activation of mitomycins to bifunctional alkylating agents

3 Bioreductive alkylation products of mitomycins with DNA: Isolation and structure of the MC-DNA cross-link

4 Mechanism of the reductive alkylation of DNA

5 Acidic activation of mitomycin C: Switch of regioselectivity of alkylation from $\mathrm{N}^{2}$ to $\mathrm{N}-7$ of guanine

6 Conformation of the mitomycin-DNA complex

7 DNA sequence specificity of the covalent reactions of mitomycin with DNA

8 Ternary mitomycin-DNA-protein interactions

9 Summary of the molecular details of mitomycin-DNA interactions: Significance for drug design 


\section{The Contributors}

Bruce C. Baguley

Cancer Research Laboratory

University of Auckland School of Medicine

Private Bag 90192

Auckland

New Zealand

\section{Christian Bailly}

Department of Pharmacology

University of Cambridge

Tennis Court Road

Cambridge CB2 1QJ

UK

\section{William A. Denny}

Cancer Research Laboratory

Auckland Division Cancer Society of New Zealand Inc.

Auckland Medical School

University of Auckland

Private Bag 90192

Auckland

New Zealand

\section{Wei-dong Ding}

Infectious Disease Research Section

Medical Research Division

Lederle Laboratories

American Cyanamid Company

Pearl River

New York 10965

USA

George A. Ellestad

Infectious Disease Research Section
Medical Research Division

Lederle Laboratories

American Cyanamid Company

Pearl River

New York 10965

USA

\section{Sidney M. Hecht}

Department of Chemistry

University of Virginia

Charlottesville

Virginia 22901

USA

\section{Jean-Pierre Hénichart}

Centre de Recherche INSERM

Place de Verdun

59045 Lille Cedex

France

\section{Warren Judd}

School of Biological Sciences

University of Auckland

Private Bag 92019

Auckland

New Zealand

\section{Kurt W. Kohn}

Laboratory of Molecular

Pharmacology

Development Therapeutics Program

National Cancer Institute

National Institutes of Health

Building 37 Room 5C25

Bethesda

Maryland 20892

USA 


\author{
Anand Natrajan \\ Department of Biology \\ University of Virginia \\ Charlottesville \\ Virginia 2290i \\ USA
}

David R. Newell

Division of Oncology

University of Newcastle upon Tyne

Cancer Research Unit

The Medical School

Framlington Place

The University

Newcastle-upon-Tyne NE2 4HH

UK

Laurence H. Patterson

Department of Pharmacy

School of Applied Sciences

De Montfort University

The Gateway

Leicester LE1 9BH

UK

Yves Pommier

Laboratory of Molecular

Pharmacology

Development Therapeutics Program

National Cancer Institute

Bethesda

Maryland 20892

USA
Raymond K. Ralph

School of Biological Sciences

University of Auckland

Private Bag 92019

Auckland

New Zealand

Farial A. Tanious

Laboratory for Chemical and Biological Sciences

Georgia State University

Atlanta

Georgia 30303

USA

\section{Maria Tomasz}

Department of Chemistry

Hunter College

City University of New York

695 Park Avenue

New York

New York 10021

USA

W. David Wilson

Department of Chemistry

Georgia State University

University Plaza

Atlanta

Georgia 30303

USA 


\section{Preface}

DNA has long been a key target for cancer chemotherapy. Indeed, the first agents to be employed clinically in the treatment of human cancer (the nitrogen mustards) are DNA cross-linking agents. Spectacular advances have occurred during recent years in the treatment of childhood leukaemia and testicular cancer, largely as a result of the development of better DNA-interactive agents. Even though the majority of solid tumours remain resistant to chemotherapy, there is real promise that a new, third-generation of platinum compounds will prove successful in the treatment of ovarian cancer. Clinical advances in such key areas are the ultimate objective of much current research in cancer chemotherapy and biology. Future progress must surely result from wise application of the large body of fundamental knowledge being accumulated from studies in a whole range of disciplines. No one doubts that clinical success will increasingly depend upon the exploitation of such knowledge and on the interplay between it and more applied disciplines. This is especially important as the molecular and cellular bases of malignant cell growth become better understood. So the study of drug-DNA interactions has moved on from the position of a dozen years ago, when our understanding of the molecular basis of drug action was relatively poor, as were the prospects for rational design of new drugs, to a much more positive position with new horizons.

These two volumes survey our current knowledge about the mode of action of the major classes of DNA-interactive antitumour agents, and in so doing provide pointers for the discovery of new therapeutic substances. The reader will notice that certain related topics have been grouped together; indeed in one instance (that of topoisomerase inhibitors), what were originally planned as two separate chapters by different authors have been amalgamated into one (by mutual consent!) so as to produce a more balanced and co-ordinated treatment. Elsewhere the 
relationships between topics may be less obvious, but we hope that our choices will stimulate cross-fertilization of ideas.

An enterprise involving many authors such as this requires the cooperation of all the contributors if it is to succeed. We are grateful to everyone for their efforts in ensuring delivery of their manuscripts promptly and for making our task as editors such a pleasurable one. Both of us are indebted to the Cancer Research Campaign for supporting work on drug-DNA interactions in our own laboratories over a number of years. To the hard-working staff of the Campaign, as well as to those who devote their lives to the alleviation of cancer at the bedside and in the laboratory, we dedicate this pair of volumes.

Sutton and Cambridge, 1993

S. N.

M. W. 